\title{
Outside of the city or outside of the law? State-of-art and challenges to the regulation of gated communities Raquel Tomanik
}

\section{Raquel Tomanik}

Doutoranda em Arquitetura e Urbanismo pela Universidade Federal de Minas Gerais. raqueltomanik@gmail.com

\begin{abstract}
The implementation of gated communities has been common practice in Brazilian cities, despite the controversy between legality and illegality of such enterprises, not provided in federal legislation dealing with urban land parceling. In the north axis of the Metropolitan Region of Belo Horizonte (MRBH), especially in the city of Lagoa Santa, this kind of occupation stands out as the predominant model of urban development. Starting with a brief discussion of the impacts of this urbanization mode, which has resulted in fragmented and dispersed cities, this paper lists the current situation of gated communities regulation as land parceling figure. It also discusses the main challenges for the implementation of this action in $\mathrm{MRBH}$ following objectives and guidelines expressed in the Integrated Development Plan of MRBH. Finally, it points out the possible impact of general repercussion thesis adopted by Supremo Tribunal Federal (Federal Supreme Court), which ratifies the local autonomy given by the Federal Constitution of 1988 and the challenges of incorporating this model of occupation to urban legislation considering the metropolitan context. What can be said about the space to be produced based on the experience of municipalities that have this mode as the main model of urban expansion? What can also be said about the municipal regulatory initiatives in MRBH? How to incorporate these enterprises to the city and to the support of the law? Such issues are discussed based on the case of Lagoa Santa city.
\end{abstract}

Keywords: Gated communities. Disperse urbanization. Urban regulation

\begin{abstract}
Resumo
A implantação de condomínios fechados tem sido prática comum em municípios brasileiros, apesar da controvérsia entre sua legalidade e ilegalidade, uma vez que esse tipo de empreedimento não está previsto na legislação federal que regula o parcelamento do solo urbano. Na Região Metropolitana de Belo Horizonte (RMBH), no eixo norte, especialmente no município de Lagoa Santa, esse tipo de ocupação destaca-se como modelo predominante de expansão urbana. Partindo de breve discussão de suas consequências na urbanização (cidades fragmentadas e dispersas), o presente artigo trata da situção atual da regulamentação dos condomínios fechados como figura de parcelamento do solo e aborda os principais desafios para a implementação dessa ação, na $\mathrm{RMBH}$, em conformidade com os objetivos e diretrizes expressos no Plano Diretor de Desenvolvimento Integrado da RMBH (PDDI $\mathrm{RMBH}$ ). Além disso, aponta os possíveis impactos da aplicação de tese de repercussão geral adotada pelo Supremo Tribunal Federal (STF) - que ratifica a autonomia municipal dada pela Constituição Federal de 1988 - e apresenta os desafios da incorporação desse modelo de parcelamento à legislação urbanística, considerando o contexto metropolitano. O que pode-se dizer do espaço a ser produzido com base na experiência de municípios que têm essa modalidade como principal modelo de expansão urbana e também das iniciativas municipais de regulamentação na $\mathrm{RMBH}$ ? Como incorporar esses empreendimentos à cidade e ao amparo da lei?
\end{abstract}


Tais questões são discutidas a partir do caso de Lagoa Santa.

Palavras-chave: Condomínios fechados. Urbanização dispersa. Regulação urbana.

\section{Resumen}

La implantación de los condominios cerrados ha sido practica comun en los ayuntamientos brasileños en que pese la controversia entre la legalidad y la ilegalidad de este tipo de emprendimiento, no previsto en la legislacion federal que trata de la subdivisión del suelo urbano. En la Region Metropolitana de Belo Horizonte $(R M B H)$, en el eje Norte, especialmente en el ayuntamiento de Lagoa Santa, este tipo de ocupación se destaca como modelo imperante de expansión urbana. Partiendo de breve discusión de los impactos de este tipo de urbanización, que tiene resuelto en ciudades fragmentadas y dispersas, el presente articulo relaciona la situación atual de la reglamentación de los condomínios cerrados como figura de subdivisión del suelo e discute los principales desafios para la implementación de esta acción en la RMBH seguiendo los objetivos y las directrices expresas en el Plano Diretor de Desenvolvimento Integrado da RMBH (PDDI RMBH). Apunta los posibles impactos de la aplicación de tesis de repercusión general adoptada por el Supremo Tribunal Federal (STF), que ratifica la autonomia del ayuntamento concedida por la Constituición Federal de 1988, y los desafios de la incorporación de este modelo de subdivisión a la legislación urbanística considerando el contexto metropolitano. ¿Lo que se puede decir del espacio a ser producido com fundamento en la experiência de ayuntamientos que tienen esta modalidade como principal modelo de expansión urbana y tambiem de las iniciativas municipales de reglamentación en la RMBH? ¿Como incorporar estes emprendimientos a la ciudad y al amparo de la ley? Tales cuestiones son discutidas a partir del caso de Lagoa Santa.

Palabras-clave: Condominios cerrados. Urbanización dispersa. Reglamentación urbana.

\section{Introdução}

1 For the purposes proposed in this article, gated communities are considered as the horizontal enterprises composed by lots or autonomous units of lands protected by fences, walls and other control devices of entrance and exit.
$\mathbf{G}$ ated communities ${ }^{1}$ have been spread out in Brazil and constitute, in certain municipalities, predominant dynamics of urban expansion. In the Metropolitan Region of Belo Horizonte (MRBH), Minas Gerais, these enterprises arise with the appeal of status, quality of life and safety for users, who are not always dwellers. While, in some regions, gated communities are directed towards leisure and / or second homes, in others, such as the municipality of Lagoa Santa, on the northern axis of the metropolis, they guarantee the space for low density residential occupation that the capital of the state does not include - either by the lack of suitable areas to receive this activity or by the sense of insecurity that a large city passes to its inhabitants.

Despite the positive acceptance by sectors of the population and also of the municipal public administrations, the gated communities constitute a controversial figure of land occupation. The impacts of this model of urbanization have been widely discussed. Apart from social 
aspects - primarily segregation - urban issues, especially the horizontal expansion of cities accompanied by the fragmentation of the urban network and dispersed urbanization, are recurrent in the bibliographic material produced on the subject.

The Integrated Development Master Plan of the Metropolitan Region of Belo Horizonte (DMP MRBH) indicates that gated communities constitute a type of land irregularity to be faced from the definition of guidelines for the use and occupation of metropolitan land (MINAS GERAIS, 2011).

The dispersion of urban forms, as a consequence of the process of urbanization, formerly composed of lower-income occupations, is characterized by the installation of projects aimed at the more affluent classes. This process is often supported by the acceptance of municipal administrations, which promote the necessary facilities for its viability. In the municipality of Lagoa Santa, it is observed the conversion of large portions of rural areas into areas of urban expansion that become propitious to the occupation by land parceling and other enterprises. In a survey on the website of the City Council of Lagoa Santa ${ }^{2}$, it is noted that the Master Plan, Law No. 2.633, of 2006, had six amendments. Three amendments modified the urban perimeter, including specific areas in the urban area or urban expansion, and thus made them apt to approve land parceling projects.

Em casos como esses, o poder público assume papel de destaque na valorização imobiliária, já que as alterações de legislação permitem aos proprietários potencializar a extração de renda a partir da terra, com a adoção de novos parâmetros de uso do solo, sem que nela seja promovida qualquer melhoria (HARVEY, 1980).

In such cases, public authorities assume a prominent role in real estate valuation, since the changes in legislation allow owners to increase the extraction of income from land, with the adoption of new parameters of land use, without any improvement (HARVEY, 1980).

Although rural areas converted into urban areas have also housed non-residential facilities, and thus conformed metropolitan regions (MONTE-MOR, 2006), the expansion of the peripheries of large cities has predominantly been in the form of gated communities. Reis (2006) emphasizes a scale of metropolitan transformation that has characterized large empty spaces interspersed with dispersed urban centers with low
2 City Council of Lagoa Santa, MG: $<$ http://www.cmlagoasanta.mg. gov.br/>. Acessed: May 2, 2016. 
population density, thus forming a fragmented and disconnected territory.

It should be noted that the dispersion of the occupation of the cities was initially promoted by the expulsion of the lower-income populations from the central areas. The process of urbanization in Brazil - accelerated in the period of industrialization -, without offering the population the conditions of employment and housing for those migrants who left the field towards the urban centers, brought about the emergence of isolated and deprived nuclei of infrastructure.

For Maricato (2001), this process in Brazil is related to reasons such as: industrial development that does not allow workers access to housing; a housing market accessible only to a small part of the population; to the public policies that favor the installation of infrastructure to make large projects feasible - among which we can highlight currently gated communities.

Reis (2006) states that the dispersed urbanization process also comes from the mobility conditions that allow the population to assume metropolitan ways of life - residence and work in different municipalities, for example. In addition, the demand for low-priced land, usually rural portions that become urban, has led to residential occupancy for areas further away from urban centers.

Starting from the scenario promoted by the dispersed urbanization brought about by the implantation of residential developments in the metropolitan peripheries, the present article presents the state-of-art of the regulation of the gated communities and, from the case of the municipality of Lagoa Santa, points out possible challenges for the regulation of this theme in the MRBH.

\section{State-of-art of the regulation of ga- ted communities}

3 Álvaro Pessoa, "The allotment and the gated communities in the Brazilian urban development" (O loteamento e o condomínio no desenvolvimento urbano brasileiro), in the informative Newsletter of the Department of Legal Assistance and Consultation to the Municipalities (of the Secretary of Justice of the State of Rio de Janeiro) 40. Year IV. December, 1978.
According to Federal Law No. 6.766, of 1979, the parceling of urban land can be done by allotment or dismemberment (BRASIL, 1979). In the case of the allotment, the traffic routes originated from the approval of the urban development project pass to the public domain in the act of registration with the real estate registry service of the respective region.

Silva (2012), citing Álvaro Pessoa3, states that the core of the discussion about the legality of gated commu- 
nities, specifically those approved as allotments - in the form of Federal Law - that become closed-ended projects, is related to the limitation of access to roads and Public places (goods of common use of the people, under the Federal Constitution of 1988) only to owners of lots located in the closed perimeter.

Another issue discussed is the fact that Federal Law No. 6.766, of 1979 , does not provide for the figure of the closed condominium, but only the parceling of urban land in the modalities of dismemberment and allotment. If the Federal Law No. 6.766, of 1979, defined only two models of land parceling, dismemberment and allotment, is it allowed to create new modalities of occupation of urban space?

Some municipal laws and regulations resemble gated communities from lots to building condos, such as apartment buildings or sets of houses built in the same lot (SILVA, 2012). Thus, these models of enterprise are linked to Federal Law No. 4.591, of 1964, which has, among other things, condominiums for buildings (BRASIL, 1964). Thus, the circulation ways are not treated as public areas, but as areas of common use of the dwellers. These acts are based on theoretical lines that state that the regulation of land parceling not included in Federal Law No. 6.766, of 1979, can be treated and regulated in municipal laws because it is a topic of local interest (MEIRELES, 2015).

This last approach is supported by what is stated in subsection VIII of Article 30 of the Federal Constitution: it is the responsibility of the municipality to "promote, as appropriate, adequate territorial planning, through planning and control of the use, urbanization and urban land occupation" (BRASIL, 1988). The municipal assignment is confirmed by what is defined in the sole paragraph of Art. 1 of Federal Law No. 6.766, of 1979: "The States, Federal District and Municipalities may establish complementary norms regarding the municipal land parceling in order to apply the law to regional and local peculiarities "(BRASIL, 1979). From these provisions, local rules and regulations may be edited for the purpose of supplementing the general rule.

In a recent decision on the constitutionality of the Complementary Law No. 710, of 2005 of the Federal District, which deals with urban development projects with special guidelines for autonomous units (DISTRITO FEDERAL, 2005), subject to extraordinary appeal (EA) ${ }^{4}$ by the Federal Prosecution Office of the Federal District and Territories (MPDFT), the Federal Supreme Court (FSC) adopted the following thesis of general repercussion ${ }^{5}$ :
4 Extraordinary appeal (EA): "An exceptional appeal to the Supreme Court against decisions of other courts, in a single or last instance, when there is an offense to the norm of the Federal Constitution. A court order may be the subject to an extraordinary appeal when: 1 - it contradicts the Constitution; 2- unconstitutionality of a treaty or Federal law; 3- it judges valid law or act of local government challenged in the face of the Constitution "(Available at: <http://www.stf.jus. br/portal/glossario/ See Verb.asp? Letter $=R \& d=207>$ Accessed on: January 5, 2016.

5 General Repercussion: "The General Repercussion is a procedural instrument inserted in the Federal Constitution of 1988 . The purpose of this tool is to enable the Supreme Court to select the Extraordinary Appeals that will analyze them, according to criteria of legal, political, social or economic relevance. The use of this appealing filter results in a reduction in the number of cases sent to the Supreme Court. Once the existence of general repercussion has been verified, the STF analyzes the merits of the matter and the decision coming from this analysis will be applied later by the inferior instances, similar cases (...) (Available at: <http://www.stf.jus. $\mathrm{br} / \mathrm{portal} / \mathrm{glossario} / \mathrm{verVerbete}$ asp ?letra $=$ A\&id $=451>$. 2016). Accessed: January 5, 2016). 
Municipalities with more than twenty thousand inhabitants and the Federal District can legislate on specific urban space planning programs and projects through laws that are compatible with the directives established in the master plan (BRASIL, 2016b, 81).

The EA proposed by Federal Prosecution Office in 2008 pointed out that the subject of urban projects with special guidelines could only be dealt with in the master plan law with due popular participation (FPG, 2008). FPO claimed that Complementary Law No. 710, of 2005, violated the Constitution in its Article 182, paragraphs 1 and 2, which defines the master plan as the basic instrument of urban policy and determines that the use of urban property must meet the law to fulfill its social function (BRASIL, 1988). Thus, the aforementioned supplementary law would be superimposed on the Master Plan.

Although the situation of gated communities is a disputed issue within the scope of urban law, this was not the central issue of the EA. According to the text, the complementary district law, in conceptualizing such urban projects with special guidelines, actually regulates the gated communities and, thus, legitimizes them as a model of urban land parceling (FPOT, 2008). In dealing with this matter, in the opinion of the FPOT, the questioned law again violates the provisions of the master plan for the purpose of issuing specific legislation outside the law that deals with district urban policy and, therefore, violates Article 182 of the Federal Constitution of 1988.

The District Complementary Law no. 710, of 2005, defines, in Paragraph 1 of Article 1, that urban development projects with special guidelines for autonomous units are integrated by autonomous units and common condominium areas under the terms of Federal Law No. 4.591, dated December 1964 (FEDERAL DISTRICT, 2005).

Regarding the relationship between urban development projects with special guidelines and Federal Law No. 4.591, of 1964, known as "building condominiums law" - such as apartment buildings - a part of the report by Minister Teori Zavaski, Judgment of the EA: the district law proposes a differentiated form of parceling of closed private lots and addresses, among other aspects, urban planning parameters to be respected. The Minister argues that the projects in question are closer to that of the allotment provided for in Federal Law No 6.766, of 1979, but that they differ for two reasons: 1 ) the possibility of closing and limiting access; 2) transfer of maintenance and conservation 
burdens to the residents. This initiative of the district law is justified by the need to regulate the modality of closed condominiums, frequent in the territory, carried out in an irregular manner and outside the control of the competent public administration (BRASIL, 2016a).

Regarding the issue of whether the modality of subdivisions and gated communities, to be legitimated, should be included in the federal legislation dealing with the urban land parceling, Minister Dias Tóffoli expressed caution regarding the approach to the theme of gated communities and their relationship with the subdivision regulated by Federal Law No. 6,766, of 1979:

\begin{abstract}
I reiterate that extreme caution is needed in setting parameters of general repercussion on the issue of subdivisions or parceling of urban land based on a specific law of the Federal District, especially when one has only a starting point and only what the Constitution says regarding the need to have a master plan for municipalities with more than twenty thousand inhabitants. (BRASIL, 2016a, 50).
\end{abstract}

Regarding the relationship between these developments and the allotment provided for in the mentioned law above, the literature provides the understanding that, although they are similar to those regulated by the law in question, the modalities differ so much "both in their regime and in their effects and results" ( SILVA, $2012,344)$. The author affirms that these closed condominiums, although they are a model of urbanization, do not constitute parceling of the ground, since they are conceived in the form of condominium. The scholar argues that, despite the subdivision in private and common units, the terrain does not lose its individuality, as occurs in the plot of allotment (SILVA, 2012).

Despite the concern about the relationship between modalities of urban land parceling, Tóffoli agrees that the theme of gated communities should be treated in the local sphere of public administration. He justifies that it is pertinent that the direction of the urban policy has been attributed to the municipalities, since these questions are of local interest and it is in the municipalities that the effects of the politics of urban planning and expansion are manifested. Therefore, the municipal administration would have greater control over such issues (BRASIL, 2016a).

The Minister's assessment is in line with Meireles's (2015) statement on subdivisions in the "Brazilian Municipal Law": "For these lots there is no specific higher legislation to guide their formation, but nothing prevents Municipalities to issue local appropriate urban norms to these urbanization" (MEIRELES, 2015, 561). 
As for the attribution of legislation on topics of local interest, Silva $(2012,63)$ states that "municipal urban norms are the most characteristic, because it is in the Municipalities that the urban activity is manifested in its most concrete and dynamic form." For the author, the Union and the States must recognize the delegation of competence given by the Federal Constitution. However, it emphasizes that the municipal administration must observe the general guidelines defined in state and federal legislation (SILVA, 2012).

The general guidelines of the national urban policy are contained in Federal Law No. 10.257, of 2011, the City Statute, which defines the requirements to be fulfilled for the preparation and review of the master plans, a basic instrument of municipal urban policy for municipalities with more than twenty thousand inhabitants or members of the metropolitan regions (BRASIL, 2001). In the field of land parceling, the general rule is established by Federal Law No. 6.766, of 1979, and therefore, state and municipal regulations must be based on this legal diploma.

The thesis of general repercussion ratifies the provisions of item VIII of Article 30 of the Federal Constitution of 1988 and is in line with the teachings of Meireles (2015) and Silva (2012). Concerning the fact that "legislation on specific urban planning programs and projects through laws that are compatible with the directives established in the master plan" (BRASIL, 2016a, 81), the decision makes clear that the regulation of new modes of land parceling by specific municipal laws must be in line with municipal urban policy guidelines. This decision reinforces the thesis that the norms of urban policy are not exhausted in the general laws - Federal Law No. 6.766, of 1979, and No. 10.257, of 2001 - and not even in the Master Plan. Therefore, there is a need to edit regulations for specific themes of city management.

Despite being clear on the attribution delegated to municipalities, the thesis of general repercussion, following the caution required by Minister Dias Tóffoli, does not deal with the theme "gated communities as a figure of land occupation". In this way, what will the application of this thesis be in the lower courts? Will states and municipalities address only the subordination of specific laws to the master plan or will they be based on the model of the district law to edit similar regulations?

The controversy between legality and illegality of gated communities confirms the mismatch between the 
legal order and the urbanization process. First the fact happens, and only then the regulation comes (ALFONSIN; FERNANDES, 2006). In an interview given in 2007, Edésio Fernandes emphasized the need not to deny the existence of the modalities of closed parceling (BARBOSA, 2008). Despite criticisms of this type of occupation, especially the type of fragmented city it produces, the interviewee defended the need to find urban, legal and environmental solutions for this already consolidated figure.

The scenario for the publication of the general repercussion thesis is similar to that of Federal Law No. 6.766 of 1979 , conceived at the same time as irregular and clandestine land parceling were already a reality in large Brazilian cities. The urbanization process in Brazil, as discussed by Campos Filho (1992) and Kowarick (1979), together with the reasons pointed out by Maricato (2001), resulted in numerous land parcelings implanted in the outskirts of large cities, beginning urban sprawl with dispersed forms, creating isolated nuclei of the central regions endowed with infrastructure.

It should be emphasized that the DMP MRBH, among the actions for territorial planning, pointed out the need to institute the figure of the urban condominium - in the terms established by Draft Bill (DB) 3.057, of 2000 , which proposes the revision of Federal Law No. 6,766 , of 1979 - as an alternative for the regulation of the closed condominiums that proliferate in the space of the metropolis (MINAS GERAIS, 2011).

If federal legislation has not regulated the figure of gated communities because they are the promoters of spaces for segregation, fragmentation and dispersion of the city due to the discontinuity of the urban network, the final question is: how will these impacts be addressed if the regulation of these enterprises by municipal laws becomes a rule?

\section{Challenges for regulation in MRBH}

The space production dynamics of the MRBH has been studied in detail, especially since 2009, due to the elaboration of the aforementioned DMP. The material from these studies, which also subsidizes the proposal of a macrozone, covering all the municipalities of the $\mathrm{MRBH}$, traces the occupation profile of the main structuring axes of the metropolis and reveals inequalities resulting from a process of separation of the areas destined to the populations of high and low income. 
Magalhães et al (2011) highlight the strong heterogeneity of the occupation of the municipalities neighboring the capital. Nova Lima and Lagoa Santa, located in the vectors of the south and north, respectively, concentrate the allotments directed to high-income layers. On the other hand, the municipalities of Contagem and Betim, to the west of Belo Horizonte, have an increasing number of enterprises destined to the low-income population. Map 1, below, presents the municipalities that compose the $\mathrm{MRBH}$, with emphasis on Nova Lima, Lagoa Santa, Contagem and Betim.

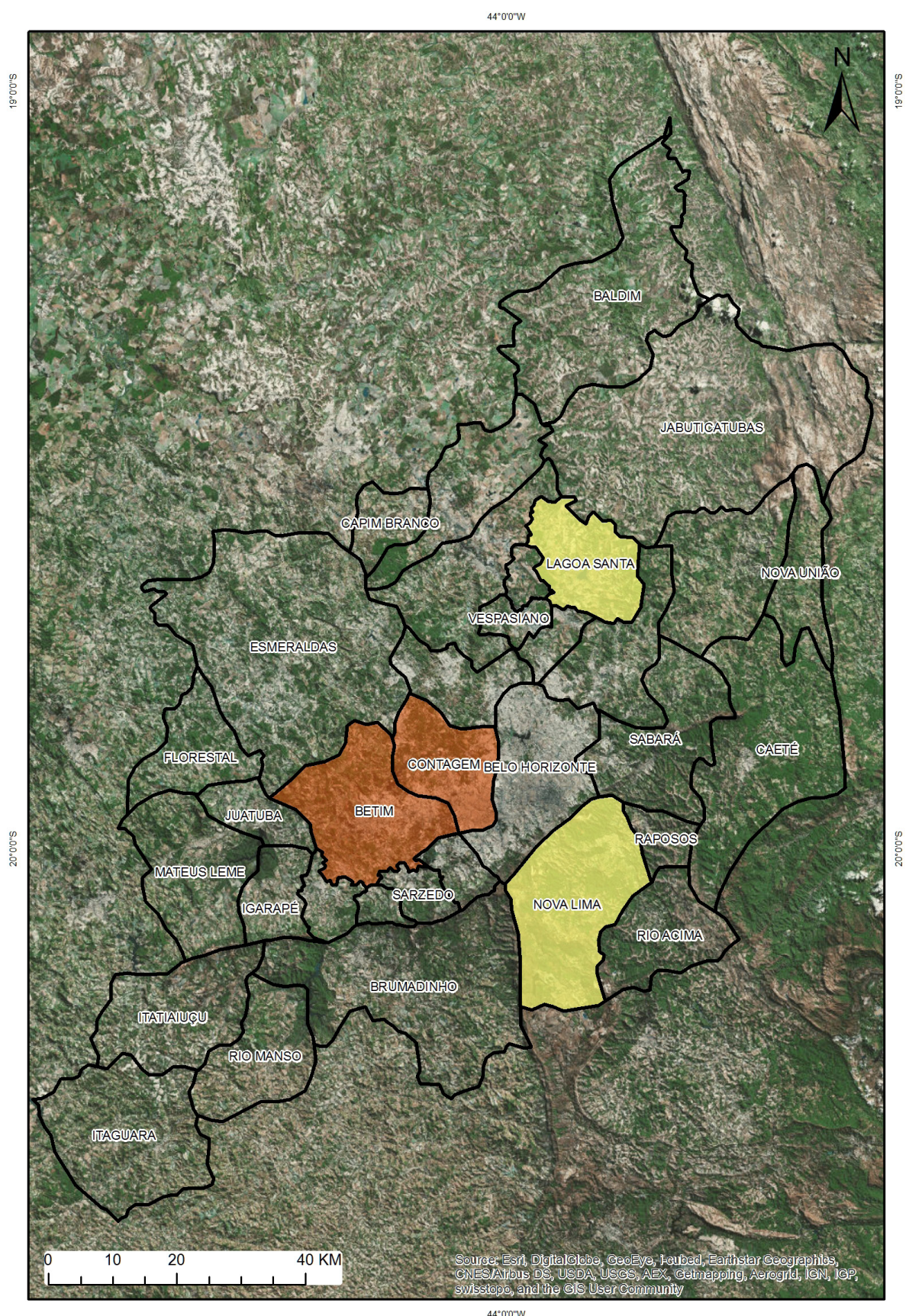

Map 1

Municipalities of RMBH - Featured: Nova Lima, Lagoa Santa, Contagem and Betim. Source: Prepared by Fabiano Couto Milagres, 2016. 
Magalhães et al also point out that municipalities historically occupied by closed allotments, such as those already mentioned, tend to avoid enterprises directed to low-income classes:

This indicates a continuation of the historical process of low-income peripheral concentration in less accessed areas, with the novelty of the peripheral areas of greater proximity to "environmental amenities" becoming the focus of the high-income peripheral concentration in the form of low density of gated communities and backcountry. In this way, a peripheral ring is created with characteristics of high income and low occupational density, mainly concentrated in the south axis, but with a tendency to extend also in the northeast between Lagoa Santa and Serra do Cipó and occasionally in some other areas of the MRBH (MAGALHÃES et al, 2011, 34).

It is also worth highlighting the proliferation of parceling in rural modules, implanted in the rural areas of the municipalities, which become closed gated communities and find obstacles to their regularization, since urban projects are only allowed in urban areas and urban expansion. These situations were also highlighted in the DMP MRBH (MINAS GERAIS, 2011).

The measure indicated to incorporate the gated communities to a specific law was the regulation of the urban condominium already foreseen in the Draft Bill 3.057, of 2000. However, it is necessary to consider the several initiatives of standardization by the municipalities, especially those attractive or that intend to attract the installation of these enterprises.

In the case of the Municipality of Lagoa Santa - whose urbanization by gated communities was boosted due to the installation of the Administrative Center of the State of Minas Gerais in the north vector of the MRBH, together with the mobility guaranteed by Highway MG 010, which gives access to the International Airport Tancredo Neves in Confins - Municipal Law No. 2.759, of 2007, land parceling law, provides for the regularization and authorization of the implementation of closed lots (LAGOA SANTA, 2007).

The closed allotment, according to the definition given by the land parceling law of Lagoa Santa, consists of an approved allotment that follows the provisions of Federal Law No. 6.766, of 1979, in which the entrepreneur intends to surround or wall the area, besides installing control devices to access it. The proposed project receives the basic municipal and metropolitan guidelines, in which the conditions for the approval of the subdivision are drawn, provides for the necessary public areas and is analyzed by the competent muni- 
cipal and state agencies. In compliance with current regulations, it receives the prior consent of the $\mathrm{MRBH}$ Development Agency (MRBH Agency) and, finally, is in a position to be approved by the municipality.

After complying with the rite of approval established by Federal Law No. 6.766, of 1979, endorsed by State Decree no. 44.646, of 2007, an instrument that regulates the examination and prior consent by the State of Minas Gerais for land parceling projects, the closure of the subdivision is analyzed in light of the municipal legislation, Law No. 2.759, of 2007, and made possible through the instrument of onerous concession of use of public areas within the perimeter to be closed, among which are the public thoroughfares.

In the basic directives document issued by the municipality, the conditions to be met for the elaboration of the urban project and subsequent implementation and closure of the enterprise are analyzed and defined. The text of the municipal law provides the following conditions for the application for closed allotments to be grant:

1. Approval of Circulation Impact Report (CIR) and Neighborhood Impact Report (NIR) under the terms of the current Master Plan, in which the necessary adaptations for the mitigation of impacts by closure should be provided - if applicable;

2. Structural and collection ways that interconnect two routes of the existing road system may not be included in the perimeter. In case of allotment to be closed, if interconnected to an existing neighborhood, this rule may be disregarded at the discretion of the municipal public works and transit agencies - which must demonstrate that the closing of the allotment will not affect circulation in the main thoroughfares of the existing neighborhood;

3. The allotment to be closed can not have an area greater than $350.000,00 \mathrm{~m}^{2}$. Undertakings with an area greater than this can be permitted only with the favorable opinion of the respective CIR and NIR.

As already mentioned, the DMP MRBH proposes the institution of the urban condominium provided for in the Draft Bill (DB) 3.057, of 2000, as a way of regulating closed condominiums in the metropolitan region. For this, it defines that the enterprises must meet the following guidelines: 
- maximum area compatible with the characteristics of the urban structure and the existence of confined areas, according to a favorable opinion of the appropriate public agency;

- $\quad$ not hampering the continuity of the existing or planned public road system;

- no formation of enclaves by the sum of several continuous condominiums, surpassing the maximum area defined for a condominium;

- mandatory for the allocation of a percentage of the area for public use, excluding the road system, and may be replaced by a donation to the Metropolitan Fund, with the approval of the competent bodies, and for projects of social interest implemented in Area of Special Social Interest, the percentage may be differentiated, from the definition in a specific law;

- mandatory location of areas of public use outside the perimeter of controlled access;

- guarantee of prediction of lots destined to non-residential uses directed to the public highway, in an area outside the perimeter of controlled access in the cases of large condominiums;

- guarantee, in exceptional landscape areas, of providing transparency of the enclosure elements of the controlled access area;

- attribution to the owners of the responsibility for the maintenance of the basic infrastructure;

- $\quad$ Projects must be submitted to integrated environmental urban licensing (MINAS GERAIS, 2011, 277, V1).

Considering the guidelines defined for a future proposal for the regulation of gated communities by the metropolitan planning body, it is observed that the related parameters go beyond those practiced in the already consolidated projects. In this sense, it is seen that one of the challenges to incorporate these enterprises in the legislation could be the clash between the measures that guarantee the quality of urban life and the aspirations of the real estate market.

From the case of Lagoa Santa, it is confirmed that municipal initiatives for the regulation of closed condominiums may be far from the guidelines established by the DMP MRBH. Despite recognizing the autonomy given to municipalities by the Federal Constitution of 1988 for dealing with urban policy, it is necessary to consider the necessary intervention of the state planning agencies in the metropolitan regions, a need reinforced by the publication of the Statute of the Metropolis - Federal Law No. 13.089, of 2015 (BRASIL, 2015). 
Although this last law legitimizes the sphere of action of state intervention in the urban policy of municipalities that are part of the metropolitan regions, the thesis of general repercussion adopted in 2016 ratifies the municipal competence to legislate on specific urban planning programs and projects. The fact that this thesis is based on the case of an initiative to regulate occupations, in the form of gated communities, supports the municipal laws issued to regulate these enterprises. In addition, it can foster new local initiatives, if the implementation of the DMP guidelines, through state law approval, demands time incompatible with the action of the private initiative. Again, we will face the mismatch between the edition of norms and the consolidated real situation.

\section{Closing remarks}

As it happens from the case of Lagoa Santa, the absence of regulation in the federal legislation for a modality of land parceling that is repeated so much in the $\mathrm{MRBH}$, as in other Brazilian municipalities, contributes to the existence and disorderly proliferation of closed allotments, in addition to encouraging the publication of municipal regulations that only institute a new legal figure without, however, establishing criteria to prevent the impacts generated by it.

The situation presented here shows that it is not enough to conceive gated communities as a figure that fits the norms and rites of federal legislation in only a part of the process or that shapes the interests of the real estate market. If this type of parceling is assumed as a form of expansion - and has been -, measures must be foreseen to be designed to integrate the urban network. Such measures are expressed in the guidelines formulated in the DMP MRBH.

The thesis of general repercussion adopted by the Supreme Court, resulting from a judgment of an extraordinary appeal that debated the constitutionality of a law that regulates the type of land occupation in gated communities, presents itself as a recent movement for the recognition of this type of enterprise in urban planning legislation.

However, it is worth preserving the reservations raised by the Ministers, especially regarding the need to foresee this figure in the law that deals with the land parceling.

Such demand can be met with the approval of the Draft Bill 3.057, of 2000, which deals with the revision of Federal Law No. 6.766, of 1979. 
Finally, it should be pointed out that the proposed regulation of closed gated communities - due to the time lag between the action and the real situation - will find a consolidated scenario and face the risk of becoming an instrument of ratification of what has been practiced due to the difficulty of breaking with the current model accustomed to the submission to the municipal norms, generally molded to the demands generated by these enterprises.

\section{References}

ALFONSIN, Betânia; FERNANDES, Edésio (Orgs). Direito Urbanístico: Estudos brasileiros e internacionais, Belo Horizonte: Del Rey, 2006.

BARBOSA, Daniela B. L. Do medo da violência à "condominiarização" das cidades brasileiras: sobre as conseqüências sócio-espaciais da modificação da legislação federal de parcelamento do solo urbano. 2008. 253f. Dissertação (Mestrado em Arquitetura e Urbanismo). Escola de Arquitetura da Universidade Federal de Minas Gerais, Belo Horizonte, 2008.

BRASIL. Constituição da República Federativa do Brasil de 1988. Disponível em:< http:// www.planalto.gov.br/ccivil_03/Constituicao/Constituicao.htm> Acesso em 18 de outubro de 2015.

BRASIL. Lei Federal no 4.591, de 16 de dezembro de 1964. Dispõe sobre o condomínio em edificações e as incorporações imobiliárias. Disponível em: <http://www.planalto.gov.br/ ccivil_03/leis/L4591.htm>. Acesso em: 10 de março de 2016.

BRASIL. Lei Federal no 6.766, de 19 de dezembro de 1979. Dispõe sobre o parcelamento do solo urbano e dá outras providências. . Disponível em: http://www.planalto.gov.br/ccivil_03/LEIS/L6766.htm Acesso em: 15 de setembro de 2015.

BRASIL. Lei Federal no 10.257, de 10 de julho de 2001. Regulamenta os arts. 182 e 183 da Constituição Federal, estabelece diretrizes gerais da política urbana e dá outras providências. Disponível em: <http://www.planalto.gov.br/ccivil_03/leis/LEIS_2001/L10257. htm>. Acesso em 10 de março de 2016.

BRASIL. Lei Federal no 13.089, de 12 de janeiro de 2015. Institui o Estatuto da Metrópole, altera a Lei no 10.257, de 10 de julho de 2001, e dá outras providências. Disponível em: < http://www.planalto.gov.br/ccivil_03/_Ato2015-2018/2015/Lei/L13089.htm>. Acesso em 02 de maio de 2016.

BRASIL. Supremo Tribunal Federal. Inteiro Teor do Acórdão - RECURSO EXTRAORDINÁRIO 607.940 Disponível em: <http://www.stf.jus.br/portal/jurisprudenciarepercussao/ verAndamentoProcesso. asp ? incidente $=3823627 \&$ numeroProcesso $=607940 \&$ classeProcesso $=$ RE\&numeroTema $=348>$. Acesso em: 09 de março de 2016. (a)

BRASIL. Supremo Tribunal Federal. Diário da Justiça Eletrônico, no 36, Disponível em: <http://www.stf.jus.br/portal/geral/verPdfPaginado.asp?id=10360112\&tipo=DJ\&descricao=DJE\%20N\%BA\%2036\%20-\%2025/02/2016>. Acesso em: 09 de março de 2016. (b)

CAMPOS FILHO, Cândido M. Cidades brasileiras: seu controle ou o caos: o que os cidadãos devem fazer para a humanização das cidades no Brasil? 2. ed. São Paulo: Studio Nobel, 1992. 
DISTRITO FEDERAL. Lei Complementar no 710, de 06 de setembro de 2005. Dispõe sobre os Projetos Urbanísticos com Diretrizes Especiais para Unidades Autônomas e dá outras providências. Disponível em: < http://legislacao.cl.df.gov.br/Legislacao/consultaTextoLeiParaNormaJuridicaNJUR-114637! buscarTextoLeiParaNormaJuridicaNJUR.action>. Acesso em: 04 de março de 2016.

HARVEY, David. A justiça social e a cidade. São Paulo: Hucitec. 1980.

KOWARICK, Lúcio. A espoliação urbana. 2. ed. Rio de Janeiro: Paz e Terra, 1979.

LAGOA SANTA. Lei $n^{\circ}$ 2.759, de 28 de dezembro de 2007. Estabelece normas para o parcelamento do solo para fins urbanos no Município de Lagoa Santa, dispõe sobre a regularização e autorização de implantação de loteamento fechado no âmbito do município, regulamenta o artigo 86, inciso III, letra f, da Lei no 2.633/2006 (Plano Diretor do Município de Lagoa Santa) e dá outras providências. <http://www.rmbh.org.br/pt-br/repositorio/municipios/lagoa-santa/plano-diretor-de-lagoa-santa-lei-2633>. Acesso em: 15 de setembro de 2015.

MAGALHÃES, Felipe. N. C; TONUCCI FILHO, João. B. M; SILVA, Harley. "Valorização imobiliária e produção do espaço: novas frentes na RMBH" In: MENDONÇA, Jupira. G; COSTA, Heloisa. S. M (Orgs). Estado e capital imobiliário: convergências atuais na produção do espaço urbano brasileiro, 17-40. Belo Horizonte: Editora C/Arte, 2011.

MARICATO, Ermínia. Brasil, cidades: alternativas para a crise urbana. Petrópolis: Vozes, 2001.

MEIRELLES, Hely Lopes. Direito municipal brasileiro, São Paulo: Malheiros, 14a ed., 2015.

MINAS GERAIS. DECRETO No 44.646, DE 31 DE OUTUBRO DE 2007. Disciplina o exame e anuência prévia pelo Estado, por meio da Secretaria de Estado de Desenvolvimento Regional e Política Urbana - SEDRU, para aprovação de projetos de loteamentos e desmembramentos de áreas para fins urbanos pelos municípios. Disponível em: <http://www.urbano. mg.gov.br/images/documentos/MUNICIPIOS/planejamentoeinfraestruturaurbana/anuenciaprevia/dec_44646_nr_dec_44768.pdf>. Acesso em: 15 de setembro de 2015.

MINAS GERAIS. Secretaria Estadual de Desenvolvimento Regional e Política Urbana. Plano diretor de desenvolvimento integrado da região metropolitana de Belo Horizonte PDDI $\mathrm{RMBH}$. Relatório de Definição das Propostas de Políticas Setoriais, Projetos e Investimentos Prioritários. Belo Horizonte: 2011, 1538p. Disponível em: <http://www.metropolitana.mg. gov.br/eixos-tematicos-integrados/relatorio-final>. Acesso em: 15 de setembro de 2015.

MINISTÉRIO PÚBLICO DO DISTRITO FEDERAL E TERRITÓRIOS. Texto integral do recurso extraordinário da ação direta de inconstitucionalidade N.0 2007.00.2.006486-7. Disponível em: http://www.mpdft.mp.br/search?client=sisrec-internet\&output=xml_no_dtd\&proxystylesheet $=$ sisrec-internet\&ie $=U T F-8 \&$ site $=$ sisrec-internet\&access $=$ p\&proxycus tom $=\% 3 \mathrm{CHOME} / \% 3 \mathrm{E} \&$ exibeCache $=$ cache: $x 47 \mathrm{QVvLXtL0]}:$ www. mpdft. $\mathrm{mp} . \mathrm{br} / \mathrm{idx} / \mathrm{sisrec} /$ $\mathrm{PUB} / \mathrm{?} \mathrm{id}=081900331820721+\mathrm{RE}+607940$ \& numeroMPDFT $=081900331820721$. Acesso em: 05 de março de 2016.

MONTE-MÓR, Roberto L. de Melo. O que é o urbano, no mundo contemporâneo. Belo Horizonte: UFMG/Cedeplar, 2006. 11p.

REIS, Nestor Goulart. Notas sobre urbanização dispersa e novas formas de tecido urbano. São Paulo: Via das Artes, 2006.

SILVA, José Afonso da. Direito urbanístico brasileiro. São Paulo, Ed. Malheiros, 7a ed, 2012. 